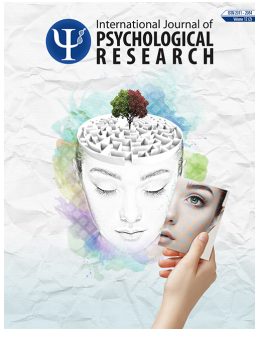

Vol $12, \mathrm{~N}^{\circ} 2$

https://revistas.usb.edu.co/index.php/IJPR ISSN 2011-2084

E-ISSN 2011-7922

\section{Psychosocial Risk Factors: its Relation with Social Cognition, Emotional Regulation and Well-Being}

Factores de riesgo psicosocial: su relación con la cognición social, la regulación emocional y el bienestar

\author{
Yaneth Urrego Betancourt ${ }^{1 \star}$, John Alexander Castro Muñoz ${ }^{1}$ \\ ${ }^{1}$ Universidad Piloto de Colombia, Colombia.
}

Editor: Jorge Mauricio Cuartas Arias, Universidad de San Buenaventura, Medellín, Colombia

Manuscript received: $18-01-2019$

Revised: 29-05-2019

Accepted: 26-06-2019.

^Corresponding author:

Yaneth Urrego Betancourt

yaneth-urrego@unipiloto.edu.co

Copyright: $\odot 2019$. International Journal of Psychological Research provides open access to all its contents under the terms of the license creative commons Attribution-NonCommercialNoDerivatives 4.0 International (CC BY-NCND 4.0)

Declaration of data availability: All relevant data are within the article, as well as the information support files.

Conflict of interests: The authors have declared that there is no conflict of interest.

\begin{abstract}
.
In Colombia, an increase of suicidal behavior in adolescents caused by personal and environmental factors is evidenced. This quantitative, descriptive, correlational research aimed to establish the existing relationship between social cognition, perception of the quality of relationships and emotional regulation with the variables of psychosocial risk, suicide risk and level of psychological well-being in adolescents in contexts of high socioeconomic vulnerability of Bogotá. A total of 155 adolescents were selected through non-probabilistic sampling at convenience, with ages between 13 and 17 years $(M=14.47$ and $D E=1.03$ ). The results allowed observing the existence of significant relationships between the study variables. From a linear regression analysis, the emotional bond and emotional self-regulation had a higher level of explanation about the perception of well-being and the psychosocial risk associated with suicide. Finally, the results and implications of a greater participation of the emotional bond in comparison to that of social cognition in adolescence are discussed, in order to formulate programs that promote well-being and prevent risk.

Resumen.

En Colombia se evidencia un aumento en la conducta suicida de los adolescentes, determinada por factores personales y ambientales. Esta investigación de tipo cuantitativa, descriptiva y correlacional tuvo como objetivo establecer la relación existente entre cognición social, percepción de la calidad de las relaciones y regulación emocional con las variables de riesgo psicosocial, riesgo suicida y nivel de bienestar psicológico en adolescentes de contextos de alta vulnerabilidad socioeconómica de Bogotá. Participaron 155 adolescentes seleccionados mediante muestreo no probabilístico a conveniencia, con edades entre los 13 y 17 años $(M=14.47$; y $D E=1.03)$. Los resultados permitieron observar la existencia de relaciones significativas entre las variables de estudio. A partir de un análisis de regresión lineal, el vínculo afectivo y la autorregulación emocional tuvieron un mayor nivel de explicación sobre la percepción de bienestar y el riesgo psicosocial asociado al suicido. Finalmente, se discuten los resultados e implicaciones de una mayor participación del vínculo afectivo en comparación al de la cognición social en la adolescencia, para la formulación de programas que promueven el bienestar y previenen el riesgo.
\end{abstract}

Keywords.

Adolescents, well-being, suicidal risk, social cognition, emotional regulation, family relations.

Palabras Clave.

Adolescentes, bienestar, riesgo suicida, cognición social, regulación emocional, relaciones familiares. 


\section{Introduction}

The concern for adolescent health has been addressed interdisciplinarily, considering unhealthy lifestyle habits a source of risk (Chen, Wang, Yang, \& Liou, 2003). However, the gaze still focuses mainly on physical health (Gortmaker, Walker, Weitzman, \& Sobol, 1990; Goodman, 1999; Moor et al., 2014; Ames, Leadbeater, \& MacDonald, 2018), and it does not acknowledge aspects of the emotional, personal and contextual order that could constitute together psychosocial risk factors.

One of these factors is suicidal risk (Lewinsohn, Rohde, \& Seeley, 1994; Gould, Fisher, Parides, Flory, \& Shaffer, 1996; Nock et al., 2013; Luby, Whalen, Tillman, \& Barch, 2019), which is associated in an important way to the presence of depressive symptoms, bullying and participation of interactive social networks (Urrego Betancourt, Quintero, \& Manrique, 2016; Klomek et al., 2013; Sourander et al., 2010; Marini, Dane, Bosacki, \& Cura, 2006; Lewinsohn, Rohde, \& Seeley, 1998; Lewinsohn, Roberts, Seeley, Rohde, \& Et, 1994; Harter, Marold, \& Whitesell, 1992; Grover \& Avasthi, 2019).

In the health of the adolescent, there is increasing concern on their self-care practices and the emotional difficulties that accompany this stage (Abraham, Lee, Nelson, Yue, \& Chow, 2015; Walker et al., 2002; Trinidad, Unger, Chou, \& Anderson, 2004; Crockett, Carlo, Wolff, \& Hope, 2016), as well as the interest in reducing dependency on parents and strengthening attachment with peers (Franz \& White, 1985; Kidwell, Dunham, Bacho, Pastorino, \& Portes, 1995; Wim \& Inge, 2010; Urrego Betancourt et al., 2014; Cui, Graber, Metz, \& Darling, 2019).

The promotion of health in this population has focused on self-care practices in physical health (Brenda \& Barbara, 2006; Mohamadian, Eftekhar Ardebili, Rahimi Foroushani, Taghdisi, \& Shojaiezade, 2011). However, as Pender (1996) points out, it includes cognition and social support (Wu, Pender, \& Noureddine, 2015). In addition, several investigations highlight the role played by the family in both health and risk prevention (Cuffe, McKeown, Addy, \& Garrison, 2005; Fatori, Bordin, Curto, \& De Paula, 2013; Ellis et al., 2017).

In the present investigation, the well-being and the psychosocial risk are considered, starting from the social cognition, a mediator in the social functioning that includes two essential components: empathy, according to Eisenberg (2000), is an emotional response that comes from understanding the state or situation of another person and is similar to what the other person is feeling; and the Theory of Mind (ToM), specified by Taylor $(1998,2006)$ Taylor $(1998,2006)$ as the inference of cognitive, motivational and affective states in others. In this regard, recent research in adolescence and young adulthood highlight the role of empathy in the processes of social interaction (Grant, 2014; Wagaman, Geiger,
Shockley, \& Segal, 2015; Van der Graaff, Carlo, Crocetti, Koot, \& Branje, 2018), as well as the role of context on its modulation and its contribution to increase psychological well-being (Coutinho, Silva, \& Decety, 2014; Melloni, Lopez, \& Ibanez, 2014; Wondra \& Ellsworth, 2015).

It also included the perception of social support (Tardy, 2006), understood as the provision or possibility of receiving support from the network, even if it is not being used (in Barrón, 1996), which has been included as an intervening factor in the promotion of health and prevention of disease (Rodrigo \& Byrne, 2011; Bekele et al., 2013; Cheng et al., 2014; Greco et al., 2014; Kwan \& Gordon, 2016).

Additionally, the perception of the quality of intrafamiliar relationships (Rivera-Heredia \& Andrade, 2010), along with the attachment, defined as one bond that is formed between itself and another, a bond that joins them in space and that lasts over time (Bowlby, 1969/1982, 1998; Ainsworth, Blehar, Waters, \& Wall, 1978), contribute into formal education contexts to the promotion of well-being in children and adolescents (Everri, Mancini, \& Fruggeri, 2015; Leme, Del, \& Coimbra, 2015; Liang, Lund, Mousseau, \& Spencer, 2016).

Another of the study variables was emotional selfregulation, given the challenges it represents in this stage of life and its importance in the prevention of suicide (Weinberg \& Klonsky, 2009; Crockett et al., 2016; Bottoms, 2013). Even more, as Gross and Thompson (2017) points out, it refers to how intrinsically each individual manages, expresses and experiences their emotions when they introduce themselves.

All these variables were studied for their explanatory value in the promotion of well-being from the perspective of eudaimonia, which states that human beings seek to live their lives the best possible way, based on their individual perspective to do it. This was proposed by Aristotle in Ethics to Nicomaco (cited by Ryff, 1989; Ryff \& Keyes, 1995; Waterman, 1990). In 1989, Carol Ryff takes and theoretically structures this perspective, considering different approaches together to positive functioning in psychology: Erikson's stages of psychosocial development $(1959,1994)$, Neugarten's continuous growth (1973), the descriptions of well-being of clinical psychology from Maslow's conceptualization (1968), Allport's formulation of maturity (1961), and Rogers's full personal functioning (1974). As a result, Ryff (1989); Ryff and Keyes (1995); Ryff and Singer (2013); Ryff et al. (2016) proposes that psychological well-being consists of the dimensions of self-acceptance, self-realization, autonomy, personal growth, quality of relationships and control of the environment. This, in turn, is conceptually related to the motivational theoretical formulation of the organismic metatheory on self-determination posed by Deci and Ryan (1987). 


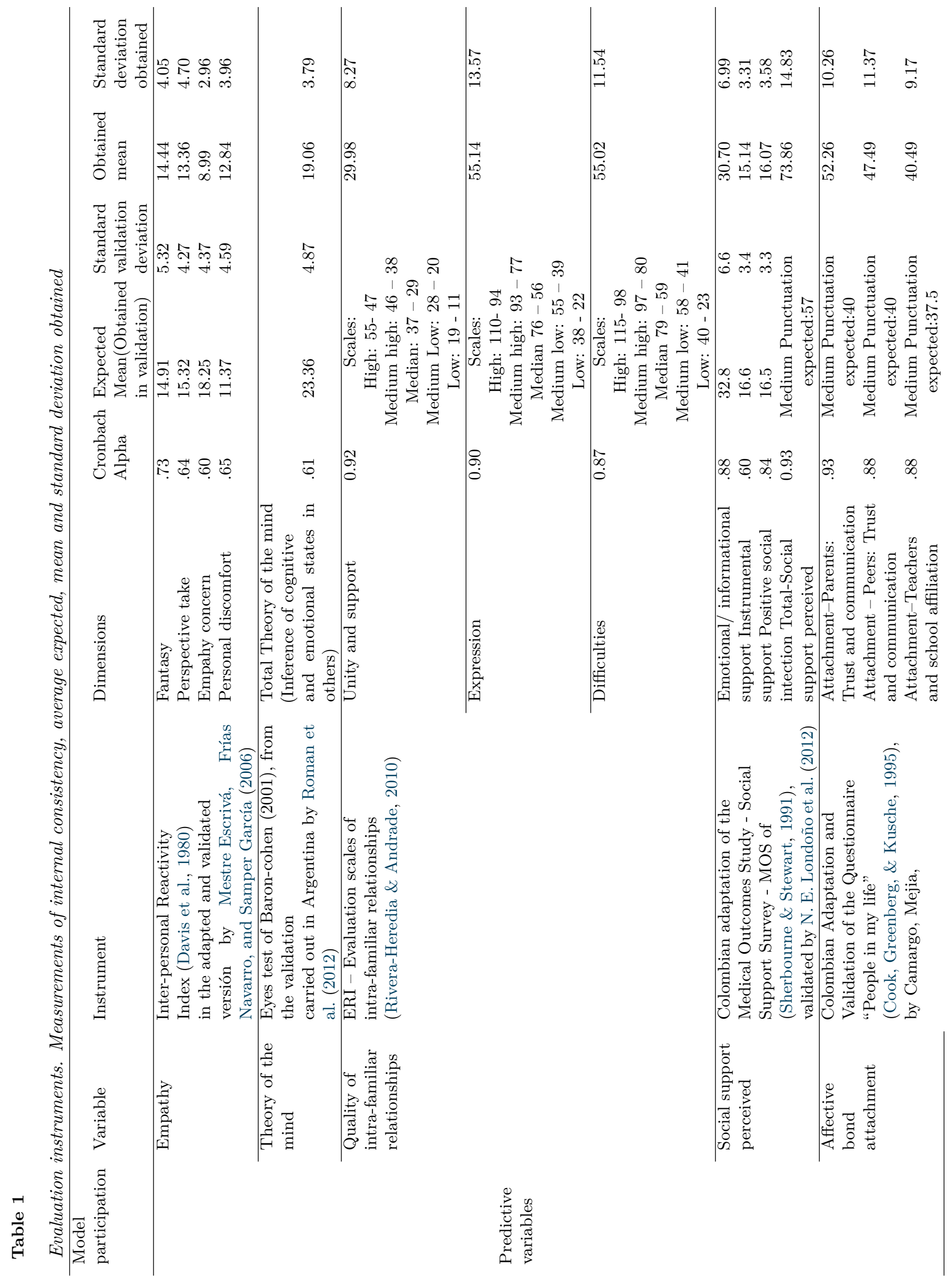




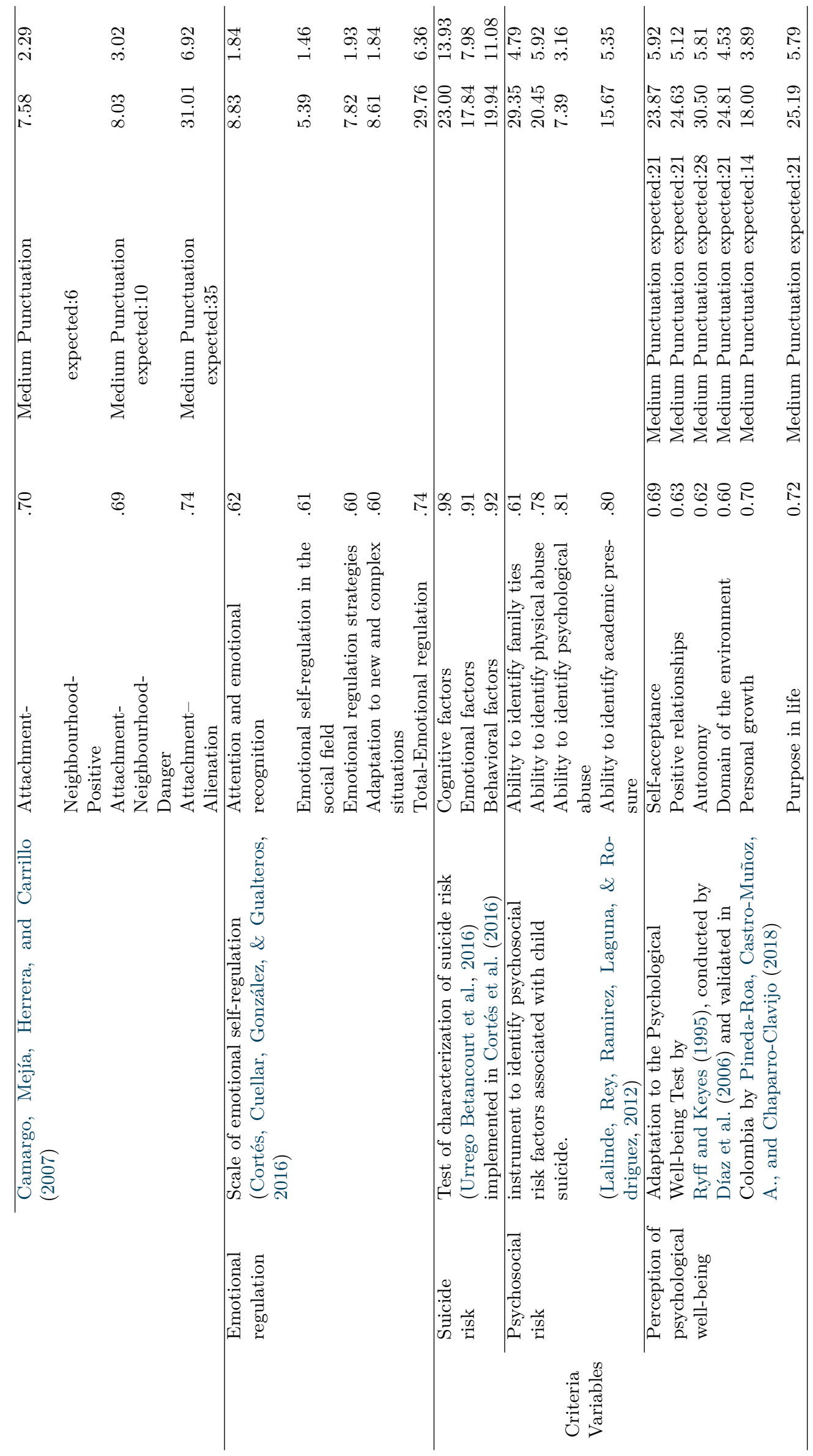




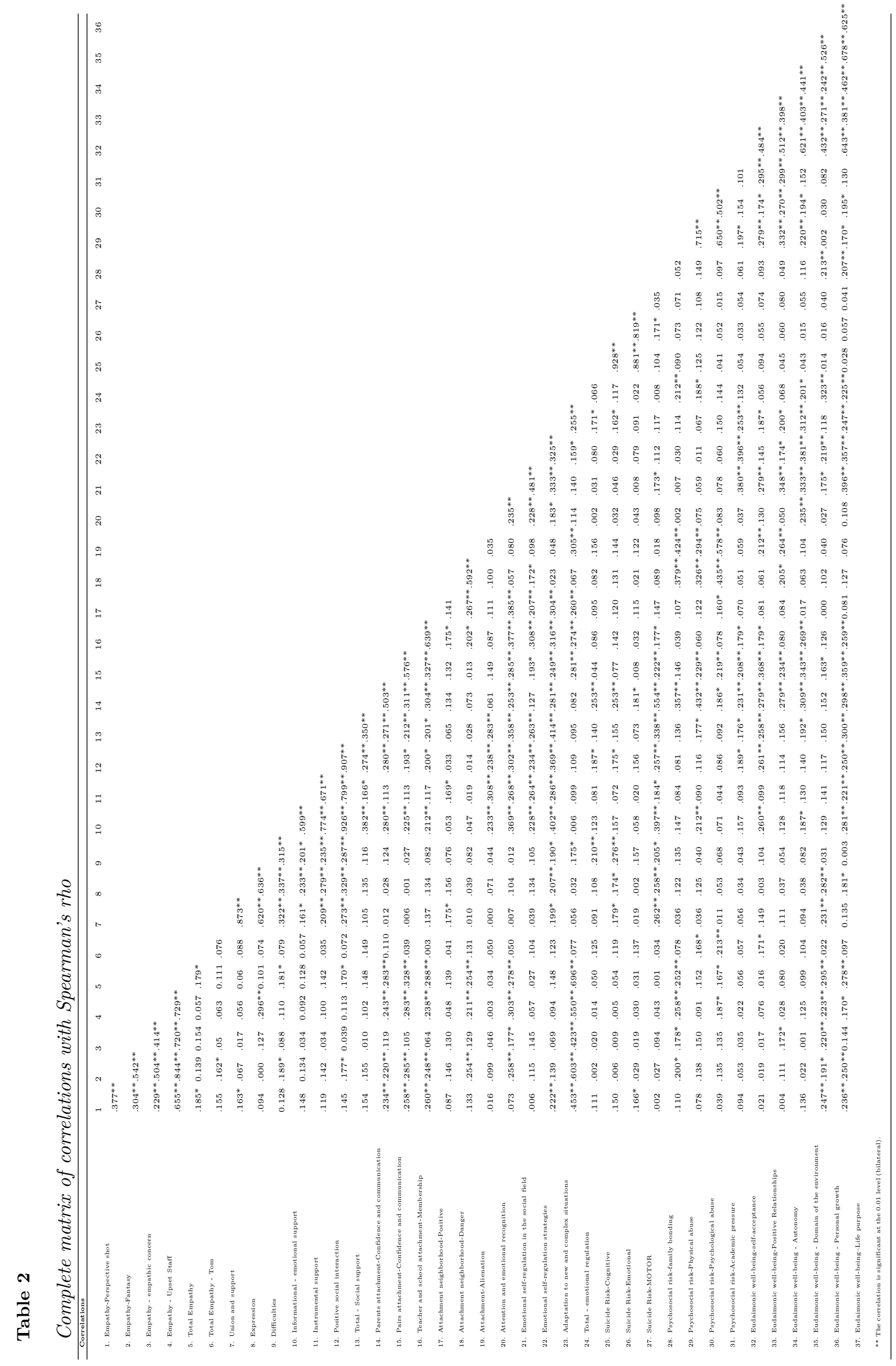


Additionally, the psychosocial risk was incorporated from the evaluation of the presence of environmental variables that include psychological and socioeconomic factors, such as problems related to the primary group, the social, educational environment (N. Londoño et al., 2010) and that represent difficulties and suicidal risk, characterized by beliefs linked to the end of life (Vargas \& Saavedra, 2012). Thus, the question that this research sought to answer was:

Is the relationship between the perception of wellbeing and the presence of psychosocial risk of suicide significant, taking into account social cognition, the perception of the quality of social and emotional relationships, and emotional regulation?

Therefore, the objective of the research was to establish the level of each of the variables in the adolescent population and to observe if the relationships between social cognition, the perception of the quality of relationships and the emotional regulation are significant in relation to the psychosocial risk, the suicidal risk and the level of psychological well-being in adolescents in highly vulnerable contexts in Bogotá

\section{Method}

\subsection{Investigation design}

This was a quantitative methodology research, of descriptive nature, with analysis of correlational data, crosssectional and non-experimental (Hernández Sampieri, Fernández Collado, \& Baptista Lucio, 2010).

\subsection{Participants}

A total of 155 adolescents from middle school (66 of 8th grade and 89 of 9th grade) participated, with a range of ages between 13 and 17 years $(M=14.47$ and $D E=1.03)$, in conditions of socio-economic vulnerability, belonging to a school in the city of Bogotá, situated in the locality of Kennedy, where there are high health tensions in the adolescent population (Hospital del Sur E.S.E, 2014) and high rates of suicide (Unidad de atención del sur, 2016). Sampling was for convenience and the data from adolescents who reported suicide attempts, and those who neither themselves nor their families wanted them to participate in the study were excluded.

\subsection{Instruments}

The instruments are presented in Table 1 , specifying the evaluated dimensions, the internal consistency levels, the expected means and the obtained means.

\subsection{Procedure}

The research was carried out in the five phases. First, identifying schools in localities with high socioeconomic vulnerability, with practice agreements and research with Universidad Piloto de Colombia. Secondly, obtaining institutional permits and signing consents (parents) and assents (teenagers). Thirdly, applying the instruments in two sessions, in order to avoid bias due to tiredness or social desirability, during two consecutive days. In the first one, the following were applied: the IRI, BaronCohen's Eyes test, the ERI, the MOS, the Emotional Self-regulation questionnaire; in the second, the suicide risk, psychosocial risk and perception of well-being tests. The applications were done in five groups, according to the distribution of students in their classrooms. The instructions were read verbally as each participant selected the answers. Two formats were created to record each one of the answers through pencil and paper. 4) Obtaining data from the typing of each of the answers to a matrix designed in Excel, according to the options of each instrument. Fifthly, analyzing results through the use of SPSS software, v.24, as well as elaborating the discussion and conclusions. Statistically, descriptive analyzes were performed through measures of central tendency (mean and standard deviation expected v. Obtained, see Table 1) and non-parametric inferential analyzes of bivariate correlation type, using Spearman's rho. Finally, linear regression analysis was carried out using the simultaneous introduction method, in which all the predictive variables are entered in order to determine those variables that best allow predicting the behavior of the research criterion variables from the level of significance (Alderete, 2006).

\section{Results}

The measurements of empathy and the theory of the mind ToM provided the average expected levels. There were high levels of perception of social support, quality in intra-familiar relationships, and attachment from parents and peers. High levels of emotional regulation and perception of well-being were observed. Finally, regarding the presence of psychosocial risk associated with suicide, low levels were reported.

Concerning the relationship between the variables (see Table 2), we can see the complete matrix composed by the relationships among the 37 evaluated dimensions from the nonparametric statistic of Spearman's rho.

In Table 3, the significant relationships with value $p<0.01$ and $R$ equal or superior to 0.3 are highlighted.

Finally, to determine the explanatory capacity of the predictive variables on the criterion variables, linear regression analyzes were performed, which are presented in Table 4.

This analysis highlights the relationship between the perception of social support, attachment and emotional self-regulation with indicators of psychosocial risk and the perception of well-being. In addition, it is possible to identify a positive relationship between the affective bond with parents and the identification of protective factors of psychosocial risk. At the same time, there is a relationship between "Alienation", a negative indicator 
Table 3

Significant relationships with $P$ value $<0.01$ and Spearman's $R$ equal to or greater than 0.3

\begin{tabular}{|c|c|}
\hline Predictive variables /Criteria variable & Spearman's rho correlation \\
\hline \multicolumn{2}{|l|}{ Perception of informational / emotional support } \\
\hline Ability to identify family ties & $.40^{* *}$ \\
\hline \multicolumn{2}{|l|}{ Total - Perception of social support } \\
\hline Ability to identify family ties & $.34^{* *}$ \\
\hline Psychological well-being - Purpose in life & $.30^{* *}$ \\
\hline \multicolumn{2}{|l|}{ Peer attachment - Trust and communication } \\
\hline Ability to identify the family bonding & $.55^{* *}$ \\
\hline Ability to identify family ties & $.31^{* *}$ \\
\hline \multicolumn{2}{|l|}{ Peer attachment - Trust and communication } \\
\hline Psychological well-being - control of the environment & $.37 * *$ \\
\hline Psychological well-being - positive relationships & $.34^{* *}$ \\
\hline Psychological well-being - control of the environment & $.36^{* *}$ \\
\hline \multicolumn{2}{|l|}{ Attachment - Danger } \\
\hline Psychological well-being - Purpose in life & $.38^{* *}$ \\
\hline Ability to identify physical abuse & $.33^{* *}$ \\
\hline Ability to identify psychological abuse & $.44^{* *}$ \\
\hline \multicolumn{2}{|l|}{ Attachment - Alienation } \\
\hline Ability to identify physical abuse & $.42^{* *}$ \\
\hline Ability to identify academic pressure & $.58^{* *}$ \\
\hline \multicolumn{2}{|l|}{ Emotional self-regulation in the social field } \\
\hline Psychological well-being - Self-acceptance & $.38^{* *}$ \\
\hline Psychological well-being - Autonomy & $.35^{* *}$ \\
\hline Psychological well-being - Domain of the environment & $.33^{* *}$ \\
\hline Psychological well-being - Purpose in life & $.39 * *$ \\
\hline \multicolumn{2}{|l|}{ Emotional self-regulation strategies } \\
\hline Psychological well-being - Self-acceptance & $.39 * *$ \\
\hline Psychological well-being - Domain of the environment & $.38^{* *}$ \\
\hline Psychological well-being - Purpose in life & $.36^{* *}$ \\
\hline \multicolumn{2}{|l|}{ Self-regulation - adaptation to new situations } \\
\hline Psychological well-being - Domain of the environment & $.31^{* *}$ \\
\hline Total emotional self-regulation & \\
\hline Psychological well-being - Personal growth & $.32^{* *}$ \\
\hline
\end{tabular}

Table 4

Multiple linear regression analysis set through the simultaneous introduction method

\begin{tabular}{|c|c|c|c|c|}
\hline $\begin{array}{l}\text { Multiple lineal } \\
\text { regression }\end{array}$ & Dependent variable / Independient & Beta & $\begin{array}{c}\text { Statistical } \\
\text { significance }\end{array}$ & $\begin{array}{l}\text { Adjusted } \\
\text { R Square }\end{array}$ \\
\hline \multirow{6}{*}{1} & Ability to identify family ties & & & \multirow{6}{*}{.34} \\
\hline & Perception of informational / emotional support & .12 & .02 & \\
\hline & Total - Perception of social support & .05 & .29 & \\
\hline & Parent attachment - Trust and communication & .03 & .00 & \\
\hline & Peer attachment - Trust and communication & .03 & .19 & \\
\hline & Ability to identify physical abuse & & & \\
\hline \multirow{3}{*}{2} & Attachment - Danger & .18 & .03 & \multirow{2}{*}{.20} \\
\hline & Attachment - Alienation & .08 & .00 & \\
\hline & Ability to identify academic pressure & & & \\
\hline \multirow{3}{*}{3} & Attachment - Danger & .14 & .08 & \multirow{3}{*}{.34} \\
\hline & Attachment - Alienation & .06 & .00 & \\
\hline & Psychological well-being - Self-acceptance & & & \\
\hline \multirow{4}{*}{4} & Emotional self-regulation in the social field & .32 & .01 & \multirow{4}{*}{.19} \\
\hline & Self-regulation - adaptation to new situations & .24 & .29 & \\
\hline & Emotional self-regulation strategies & .24 & .00 & \\
\hline & Total emotional self-regulation & .06 & .61 & \\
\hline \multirow{8}{*}{5} & Psychological well-being - Domain of the environment & & & \multirow{8}{*}{.24} \\
\hline & Total emotional self-regulation & .26 & .28 & \\
\hline & Emotional self-regulation in the social field & .20 & .18 & \\
\hline & Self-regulation - adaptation to new situations & .19 & .00 & \\
\hline & Emotional self-regulation strategies & .05 & .36 & \\
\hline & Total emotional self-regulation & .04 & .09 & \\
\hline & Parent attachment - Trust and communication & .03 & .08 & \\
\hline & Psychological well-being - Purpose in life & & & \\
\hline \multirow{4}{*}{6} & Peer attachment - Trust and communication & .33 & .020 & \multirow{4}{*}{.24} \\
\hline & Emotional self-regulation in the social field & .24 & .023 & \\
\hline & Emotional self-regulation strategies & .03 & .002 & \\
\hline & Peer attachment - Trust and communication & .03 & .132 & \\
\hline
\end{tabular}


of attachment, as a predictor of psychosocial risk. Finally, the indicators of the perception of well-being are affected by the strategies of emotional self-regulation and by the affective bond with parents and peers.

\section{Discussion}

In the study sample, the expected levels of social cognition and emotional regulation were presented. Although these levels may be influenced by the $\mathrm{n}$ of the sample and because only one educational institution was included, adolescents are in a stage where social relationships with their peers are important, which implies the use of skills to infer the cognitive, motivational and affective states of others (Taylor, 2006). In this regard, the capacity for mentalization helps to understand emotions and generate empathy.

Regarding the level of significance, the role of social cognition in the perception of well-being and risk prevention was reaffirmed in these findings (Melloni et al., 2014; Wondra \& Ellsworth, 2015; Taylor, 2006; Davis, 2017). This relationship was only evidenced from some dimensions, especially personal growth and life purpose, and although it was significant, it was not strong. However, it can be seen in clinical implications how the role of having clear goals and generating conditions for the development of potentialities can be effective in preventing situations that lead to health deterioration. School levels and the stage of life can also explain the score, as adolescents are approaching the end of their basic cycle and bit by bit they become more reflective about their future.

The results also showed a relationship between the perception of the quality of intra-familiar relationships and the promotion of well-being, both evaluative variables on social interactions and the processes involved (Taylor, 2006; Davis, 2017).

In the same direction, but with greater strength in the association, the affective bond was related to the perception of well-being and psychosocial risk. The importance of attachment to parents and peers and their association with well-being (Urrego Betancourt et al., 2014), was confirmed. And contrary to what has been found on reducing dependence on parents (Franz \& White, 1985; Kidwell et al., 1995; Wim \& Inge, 2010), which the study group shows, is that the support received by parents is found to be a protective factor and an aspect to be taken into account in the caring practices and the perception in the sense of well-being. On the other hand, it is interesting to find that according to what is reported in the health indicators (Hospital del Sur E.S.E, 2014; Unidad de atención del sur, 2016), the participants' school location presents several psychosocial risks, tensions in health and suicidal behavior. Those aspects were not evident in the sample, and that confirms once again the protective role found in other investigations of the links with parents and peers and their role in promoting well-being (Everri et al., 2015; Leme et al., 2015; Liang et al., 2016), which should be integrated into the design of effective suicide prevention and welfare promotion programs.

In the same direction, the role of emotional selfregulation was observed, although it was only linked to the perception of psychological well-being (Gross \& Thompson, 2017; Crockett et al., 2016). No strong association was found to suicide risk because the results were within the expected mean. In other words, despite the fact that there was no causal relationship, a greater perception of psychosocial risk and a lower suicide risk could be established indirectly.

\section{Conclusions}

The results show that in adolescence, the explanatory capacity of the factors coming from affective relationships continues to be greater. (Bowlby, 1969/1982, 1998; Ainsworth et al., 1978; Liang et al., 2016; RodríguezFernández et al., 2016; Cui et al., 2019; Grover \& Avasthi, 2019).

These findings, despite the limitations related to the sample size and the type of sampling, suggest that, in order to intervene, with the purpose of promoting adolescent health and wellbeing, it is important to strengthen the affective bond and the emotional self-regulation strategies as central sources, without ignoring the role of social cognition and the perception of social support in this population.

It is suggested to continue with studies that expand the sample, validate the relationship of the variables, including different sociodemographic characteristics and the protective factors found here, in the design of programs that help to reduce suicide, being a daily problem that has increased in a vertiginous way in groups of adolescents and children.

\section{References}

Abraham, A., Lee, A., Nelson, E. A. S., Yue, J. S., \& Chow, S. W. (2015). A school-based health promotion program to promote physical activity among young adolescents in hong kong. Journal of Adolescent Health, 56(2), S18. doi:10.1016/j.jadohealth.2014.10.037.

Ainsworth, M., Blehar, M., Waters, E., \& Wall, S. (1978). Patterns of attachment. lawrence hillsdale. NJ: Erlbaum.

Alderete, A. M. (2006). Fundamentos del análisis de regresión logística en la investigación psicológica. Revista Evaluar, 6(1), 52-67. Retrieved from https://revistas.unc.edu.ar/index.php/revaluar/ article/view/534. 
Allport, G. W. (1961). Pattern and growth in personality. New York: Holt, Reinhart \& Winston.

Ames, M. E., Leadbeater, B. J., \& MacDonald, S. W. (2018). Health behavior changes in adolescence and young adulthood: Implications for cardiometabolic risk. Health Psychology, 37(2), 103. doi:10.1037/hea0000560.

Barrón, A. (1996). Apoyo social. aspectos teóricos y aplicaciones. Madrid, España: Siglo Veintiuno, España Editores, S.A.

Bekele, T., Rourke, S. B., Tucker, R., Greene, S., Sobota, M., Koornstra, J., ... others (2013). Direct and indirect effects of perceived social support on health-related quality of life in persons living with hiv/aids. AIDS care, 25(3), 337-346. doi:10.1080/09540121.2012.701716.

Bottoms, H. C. (2013). Pathways to social functioning via emotion regulation in people with serious mental illness (PhD dissertation). University of Nebraska, Lincoln, NE.

Bowlby, J. (1969/1982). El vínculo afectivo (el apego). Barcelona: Paidós.

Bowlby, J. (1998). El apego y la pérdida 1: El apego. Barcelona: Paidós.

Brenda, J., \& Barbara, V.-F. (2006). Health promotion in adolescents: A review of pender's health promotion model. Nursing Science Quarterly, 19(4), 366-373.

Camargo, S., Mejía, G., Herrera, A., \& Carrillo, S. (2007). Adaptación del cuestionario "personas en mi vida" en niños y niñas bogotanos entre 9 y 12 años de edad. Acta Colombiana de Psicología, 10(2), 8393.

Chen, M.-Y., Wang, E. K., Yang, R.-J., \& Liou, Y.-M. (2003). Adolescent health promotion scale: development and psychometric testing. Public Health Nursing, 20(2), 104-110. doi:10.1046/j.15251446.2003.20204.x.

Cheng, Y., Li, X., Lou, C., Sonenstein, F. L., Kalamar, A., Jejeebhoy, S., ... Ojengbede, O. (2014, December). The association between social support and mental health among vulnerable adolescents in five cities: findings from the study of the well-being of adolescents in vulnerable environments. Journal of Adolescent Health, 55(6), S31-S38. doi:10.1016/j.jadohealth.2014.08.020.

Cook, E., Greenberg, M. T., \& Kusche, C. (1995). People in my life: Attachment relationships in middle childhood. Society for Research in Child Development, Indianapolis, IN.

Cortés, L., Cuellar, Y., González, P., \& Gualteros, D. (2016). Diseño y validación de un programa de autorregulación emocional para prevenir la ideación suicida en la infancia y la adolescencia. Con-textos, $15,1-11$.

Coutinho, J. F., Silva, P. O., \& Decety, J. (2014). Neurosciences, empathy, and healthy interpersonal re- lationships: Recent findings and implications for counseling psychology. Journal of Counseling Psychology, 61(4), 541. doi:10.1037/cou0000021.

Crockett, L. J., Carlo, G., Wolff, J. M., \& Hope, M. O. (2016). The role of pubertal timing and temperamental vulnerability in adolescents' internalizing symptoms. Development and psychopathology, 25 (2), 377-389. doi:10.1017/S0954579412001125.

Cuffe, S. P., McKeown, R. E., Addy, C. L., \& Garrison, C. Z. (2005). Family and psychosocial risk factors in a longitudinal epidemiological study of adolescents. Journal of the American Academy of Child \& Adolescent Psychiatry, 44(2), 121-129. doi:10.1097/00004583-200502000-00004.

Cui, M., Graber, J. A., Metz, A., \& Darling, C. A. (2019). Parental indulgence, self-regulation, and young adults' behavioral and emotional problems. Journal of Family Studies, 25(3), 233-249. doi:10.1080/13229400.2016.1237884.

Davis, M. H. (2017). Empathy, compassion, and social relationships. En: Seppala, E., Simon-Thomas E., Brown, S., Worline, M., Cameron, C. \& Doty, J. The Oxford Handbook of Compassion Science.

Davis, M. H., et al. (1980). A multidimensional approach to individual differences in empathy. Catalog of Selected Documents in Psychology, 10(85), 1-17.

Deci, E. L., \& Ryan, R. M. (1987). The support of autonomy and the control of behavior. Journal of personality and social psychology, 53(6), 1024. doi:10.1037/0022-3514.53.6.1024.

Díaz, D., Rodríguez-Carvajal, R., Blanco, A., MorenoJiménez, B., Gallardo, I., Valle, C., \& Dierendonck, D. v. (2006). Adaptación española de las escalas de bienestar psicológico de ryff. Psicothema, 18(3), $572-577$.

Eisenberg, N. (2000). Emotion, regulation, and moral development. Annual review of psychology, 51, 665-697. doi:10.1146/annurev.psych.51.1.665.

Ellis, R. E., Seal, M. L., Simmons, J. G., Whittle, S., Schwartz, O. S., Byrne, M. L., \& Allen, N. B. (2017). Longitudinal trajectories of depression symptoms in adolescence: psychosocial risk factors and outcomes. Child Psychiatry $\&$ Human Development, 48(4), 554-571. doi:10.1007/s10578016-0682-z.

Erikson, E. H. (1959). Identity and the life cycle: Selected papers.

Erikson, E. H. (1994). Identity and the life cycle. WW Norton \& Company.

Everri, M., Mancini, T., \& Fruggeri, L. (2015). Family functioning, parental monitoring and adolescent familiar responsibility in middle and late adolescence. Journal of Child and Family Studies, 24 (10), 3058-3066. doi:10.1007/s10826-014-0109-z.

Fatori, D., Bordin, I. A., Curto, B. M., \& De Paula, C. S. (2013). Influence of psychosocial risk factors 
on the trajectory of mental health problems from childhood to adolescence: a longitudinal study. BMC psychiatry, 13(1), 31.

Franz, C. E., \& White, K. M. (1985). Individuation and attachment in personality development: Extending erikson's theory. Journal of personality, 53(2), 224-256.

Goodman, E. (1999). The role of socioeconomic status gradients in explaining differences in us adolescents' health. American journal of public health, 89(10), 1522-1528.

Gortmaker, S. L., Walker, D. K., Weitzman, M., \& Sobol, A. M. (1990). Chronic conditions, socioeconomic risks, and behavioral problems in children and adolescents. Pediatrics, 85(3), 267-276.

Gould, M. S., Fisher, P., Parides, M., Flory, M., \& Shaffer, D. (1996). Psychosocial risk factors of child and adolescent completed suicide. Archives of general psychiatry, 53(12), 1155-1162.

Grant, L. (2014). Hearts and minds: Aspects of empathy and wellbeing in social work students. Social Work Education, 33(3), 338-352. doi:10.1080/02615479.2013.805191.

Greco, A., Steca, P., Pozzi, R., Monzani, D., D’Addario, M., Villani, A., ... Parati, G. (2014). Predicting depression from illness severity in cardiovascular disease patients: self-efficacy beliefs, illness perception, and perceived social support as mediators. International journal of behavioral medicine, 21(2), 221-229. doi:10.1007/s12529-013-9290-5.

Gross, J. J., \& Thompson, R. A. (2017). Emotion regulation: Conceptual foundations. In J. J.Gross (Ed.), Handbook of emotion regulation. New York: Guilford Press. New York: Guilford Press.

Grover, S., \& Avasthi, A. (2019). Clinical practice guidelines for the management of depression in children and adolescents. Indian journal of psychiatry, 61(2), 226-240. Retrieved from https://dx.doi.org/10.4103\%2Fpsychiatry.Indian JPsychiatry_563_18.

Harter, S., Marold, D. B., \& Whitesell, N. R. (1992). Model of psychosocial risk factors leading to suicidal ideation in young adolescents. $D e$ velopment and Psychopathology, 4(1), 167-188. doi:10.1017/S0954579400005629.

Hernández Sampieri, R., Fernández Collado, C., \& Baptista Lucio, P. (2010). Metodología de la investigación.

Hospital del Sur E.S.E. (2014). Diagnóstico local con participación social: Localidad de kennedy. Retrieved from http://www.shorturl.at/dtzdo.

Kidwell, J. S., Dunham, R. M., Bacho, R. A., Pastorino, E., \& Portes, P. R. (1995). Adolescent identity exploration: A test of erikson's theory of transitional crisis. Adolescence, 30(120), 785-794.

Klomek, A. B., Kleinman, M., Altschuler, E., Marrocco,
F., Amakawa, L., \& Gould, M. S. (2013). Suicidal adolescents' experiences with bullying perpetration and victimization during high school as risk factors for later depression and suicidality. Journal of Adolescent Health, 53(1), 37-42. doi:10.1016/j.jadohealth.2012.12.008.

Kwan, M. Y., \& Gordon, K. H. (2016). The effects of social support and stress perception on bulimic behaviors and unhealthy food consumption. Eating behaviors, 22, 34-39. doi:10.1016/j.eatbeh.2016.03.024.

Lalinde, A., Rey, B., Ramirez, C., Laguna, J., \& Rodriguez, R. (2012). Instrumento para identificar factores de riesgo psicosociales asociados al suicidio infantil (Bachelor's thesis for degree in Psychology). Universidad Piloto de Colombia.

Leme, V., Del, P., \& Coimbra, S. (2015). Social skills, social support and well-being in adolescents of different family configurations. Paidéia (Ribeirão Preto), 25 (60), 9-17. doi:10.1590/1982-43272560201503.

Lewinsohn, P. M., Roberts, R. E., Seeley, J. R., Rohde, P., \& Et, P. (1994). Adolescent psychopathology: Ii. psychosocial risk factors for depression. Journal of Abnormal Psychology, 103(2), 302-315.

Lewinsohn, P. M., Rohde, P., \& Seeley, J. (1994). Psychosocial risk factors for future adolescent suicide attempts. Journal of Consulting and Clinical Psychology, 62 (2), 297-305. doi:10.1037/0022006X.62.2.297.

Lewinsohn, P. M., Rohde, P., \& Seeley, J. (1998). Major depressive disorder in older adolescents: Prevalence, risk factors, and clinical implications. Clinical Psychology Review, 18(7), 765-794. doi:10.1016/S0272-7358(98)00010-5.

Liang, B., Lund, T., Mousseau, A., \& Spencer, R. (2016, September 01). The mediating role of engagement in mentoring relationships and self-esteem among affluent adolescent girls. Psychology in the Schools, 53(8), 848-860. doi:10.1002/pits.21949.

Londoño, N., Marín, C., F., J., J., P., O., M., Escobar, B., \& López, I. (2010). Factores de riesgo psicosociales y ambientales asociados a trastornos mentales. Suma Psicológica, 17(1), 59-68.

Londoño, N. E., Rogers, H., Castilla, J., Posada, S., Ochoa, N., Jaramillo, M., ... Aguirre, D. (2012). Validación en colombia del cuestionario mos de apoyo social. International Journal of Psychological Research, 5(1), 142-150.

Luby, J., Whalen, D., Tillman, R., \& Barch, D. (2019, September 01). Clinical and psychosocial characteristics of young children with suicidal ideation, behaviors, and nonsuicidal self-injurious behaviors. Journal of the American Academy of Child \& Adolescent Psychiatry, 58(1), 117-127. doi:10.1016/j.jaac.2018.06.031.

Marini, Z., Dane, A., Bosacki, S., \& Cura, Y. (2006). 
Direct and indirect bully-victims: differential psychosocial risk factors associated with adolescents involved in bullying and victimization. Aggressive Behavior, 32 (6), 551-569. doi:10.1002/ab.20155.

Maslow, A. (1968). Toward a psychology of being (2nd ed.). New York, NY: Van Nostrand.

Melloni, M., Lopez, V., \& Ibanez, A. (2014). Empathy and contextual social cognition. Cognitive, Affective 85 Behavioral Neuroscience, 14(1), 407-425. doi:10.3758/s13415-013-0205-3.

Mestre Escrivá, V., Frías Navarro, M. D., \& Samper García, P. (2006). La medida de la empatía: análisis del interpersonal reactivity index. Psicothema (Oviedo), 16 (2), 255-260.

Mohamadian, H., Eftekhar Ardebili, H., Rahimi Foroushani, A., Taghdisi, M., \& Shojaiezade, D. (2011). Evaluation of pender's health promotion model for predicting adolescent girls' quality of life. Journal of School of Public Health 83 Institute of Public Health Research, 8(4), $1-13$.

Moor, I., Rathmann, K., Stronks, K., Levin, K., Spallek, J., \& Richter, M. (2014). Psychosocial and behavioural factors in the explanation of socioeconomic inequalities in adolescent health: a multilevel analysis in 28 european and north american countries. Journal of Epidemiology and Community Health, 68(10), 912-921. doi:10.1136/jech2014-203933.

Neugarten, B. (1973). Personality change in late life: A developmental perspective. in c. eisdorfer $\& \mathrm{~m}$. p. lawton (eds.), the psychology of adult development and aging (pp. 311-335). Washington, DC: American Psychological Association.

Nock, M., Green, J., Hwang, I., Sampson, N., Zaslavsky, A., Kessler, R., \& McLaughlin, K. A. (2013). Prevalence, correlates, and treatment of lifetime suicidal behavior among adolescents: Results from the national comorbidity survey replication adolescent supplement. Jama Psychiatry, 70(3), 300-310. doi:10.1001/2013.jamapsychiatry.55.

Pender, N. (1996). Health promotion in nursing practice (3rd ed.). Stanford, CT: Appleton and Lange.

Pineda-Roa, C. A., Castro-Muñoz, A., J., \& ChaparroClavijo, R. A. (2018). studio psicométrico de las escalas de bienestar psicológico de ryff en adultos jóvenes colombianos. E. Pensamiento Psicológico, 16 (1), 44-45. doi:10.11144/Javerianacali.PPSI161.epeb.

Rivera-Heredia, M., \& Andrade, P. (2010). Escala de evaluación de las relaciones intrafamiliares (e.r.i.). Uaricha Revista de Psicología, 14, 12-29.

Rodríguez-Fernández, A., Ramos-Díaz, E., FernándezZabala, A., Goñi, E., Esnaola, I., \& Goñi, A. (2016). Contextual and psychological variables in a descriptive model of subjective well-being and school engagement. International Journal of Clinical and Health Psychology, 16(2), 166-174.

Rodrigo, M., \& Byrne, S. (2011). Social support and personal agency in at-risk mothers. Psychosocial Intervention, 20(1), 13-24. doi:10.5093/in2011v20n1a2.

Rogers, C. (1974). Toward becoming a fully functioning person. Readings in Human Development: A Humanistic Approach, 33, 33-45.

Roman, F., Galeno, R., Roman, N., Iturry, M., Blanco, R., Leis, A., ... Allegri, R. (2012). Baremos del test de la mirada en español en adultos normales de buenos aires. Revista Neuropsicología Latinoamericana, 4(3), 1-5.

Ryff, C. (1989). Happiness is everything or is it? explorations of the meaning of psychological wellbeing. Journal of Personality and Social Psychology, 57(6), 1069-1081.

Ryff, C., \& Keyes, C. (1995). The structure of psychological well-being revisited. Journal of Personality and Social Psychology, 69(4), 719-727.

Ryff, C., Kitayama, S., Karasawa, M., Markus, H., Kawakami, N., \& Coe, C. (2016). Survey of midlife development in japan (midja 2), may-october 2012. Ann Arbor, MI: Inter-university Consortium for Political and Social Research.

Ryff, C., \& Singer, B. (2013). Know thyself and become what you are: A eudaimonic approach to psychological well-being. in delle, a. (ed.), the exploration of happiness. happiness studies book series (pp. 97116). New York, NY: Springer.

Sherbourne, C., \& Stewart, A. (1991). The mos social support survey. Social Science and Medicine, 32(6), 705-714. doi:10.1016/0277-9536(91)90150-B.

Sourander, A., Brunstein, K. A., Ikonen, M., Lindroos, J., Luntamo, T., Koskelainen, M., ... Helenius, H. (2010). Psychosocial risk factors associated with cyberbullying among adolescents. Archives of General Psychiatry, 67(7), 720-728. doi:10.1001/archgenpsychiatry.2010.79.

Tardy, C. H. (2006). Social support meassurement. American Journal of Community Psychology, 13(2), 187202.

Taylor, S. E. (1998). The social being in social psychology. in d. t. gilbert, s. t. fiske, \& g. lindzey (eds.). the handbook of social psychology (4th ed., vol. 1, pp. 58-95). New York, NY: McGraw-Hill.

Taylor, S. E. (2006). Health psychology (6th ed.). New York, NY: McGraw-Hill.

Trinidad, D., Unger, J., Chou, C., \& Anderson, J. (2004). The protective association of emotional intelligence with psychosocial smoking risk factors for adolescents. Personality and Individual Differences, 36 (4), 945-954. doi:10.1016/S0191-8869(03)001636.

Unidad de atención del sur. (2016). Atlas de salud pública. localidad de kennedy. Retrieved from 
http://www.saludcapital.gov.co/DSP/Documentos \%20Vigilancia\%20en \%20Salud \%20Pblica\%20 Geogrfica1/An\%C3\%A1lisis\%20espacial\%20por \%20localidad/Atlas\%20de\%20Salud\%20P\%C3\% BAblica/2016/Atlas\%20de\%20Salud\%20P\%C3\% BAblica\%20Kennedy\%20.pdf.

Urrego Betancourt, Y., Quintero, A., \& Manrique, J. (2016). Caracterización de adolescentes con conductas suicidas a través de redes sociales; facebook, foros y open-blogs. in asunived (ed.), avances de investigación en salud a lo largo del ciclo vital ( $p p$. 77-86). Almeria, España: ASUNIVEP.

Urrego Betancourt, Y., Restrepo, J., Pinzon, S., Acosta, J., Diaz, M., \& Bonilla, C. (2014). Vínculo afectivo en pares y cognición social en la infancia intermedia. International Journal of Psychological Research, $7(2), 51-63$.

Van der Graaff, J., Carlo, G., Crocetti, E., Koot, H. M., \& Branje, S. (2018). Prosocial behavior in adolescence: gender differences in development and links with empathy. Journal of youth and adolescence, 47(5), 1086-1099. doi:10.1007/s10964-017-0786-1.

Vargas, H., \& Saavedra, J. E. (2012). Prevalencia y factores asociados con la conducta suicida en adolescentes de lima metropolitana y callao. Revista peruana de Epidemiología, 16(3), 1-11.

Wagaman, M. A., Geiger, J. M., Shockley, C., \& Segal, E. A. (2015). The role of empathy in burnout, compassion satisfaction, and secondary traumatic stress among social workers. Social Work, 60(3), 201-209.

Walker, Z., Townsend, J., Oakley, L., Donovan, C., Smith, H., Hurst, Z., ... Marshall, S. (2002). Primary care - health promotion for adolescents in primary care: Randomised controlled trial. BMJ: British Medical Journal, 325(7363), 524-529. doi:10.1136/bmj.325.7363.524.

Waterman, A. (1990). The relevance of aristotle's conception of eudaimonia for the psychological study of happiness. Theoretical \& Philosophical Psychology, 10 (1), 39-44. doi:10.1037/h0091489.

Weinberg, A., \& Klonsky, E. D. (2009). Measurement of emotion dysregulation in adolescents. Psychological Assessment, 21(4), 616-621. doi:10.1037/a0016669.

Wim, B., \& Inge, S.-K. (2010). Does identity precede intimacy? testing erikson's theory on romantic development in emerging adults of the 21st century. Journal of Adolescent Research, 25(3), 387-415. doi:10.1177/2F0743558410361370.

Wondra, J. D., \& Ellsworth, P. C. (2015). An appraisal theory of empathy and other vicarious emotional experiences. Psychological Review, 122(3), 411428. doi:10.1037/a0039252.

Wu, T.-Y., Pender, N., \& Noureddine, S. (2015). Gender differences in the psychosocial and cog- nitive correlates of physical activity among taiwanese adolescents: A structural equation modeling approach. International Journal of Behavioral Medicine, 10(2), 93-105. 